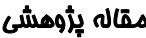

\section{آكاهى مادران شهرستان شيروان در زمينه بهداشت دهان و دندان كودكان و-1 سال}

\author{
زهرا نظرى'، معصومه طاهريور ب*

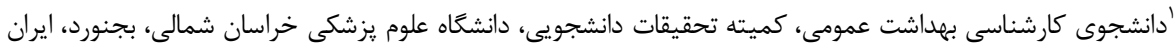

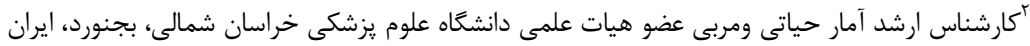

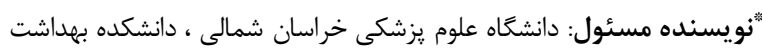

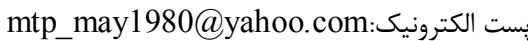
جكيده

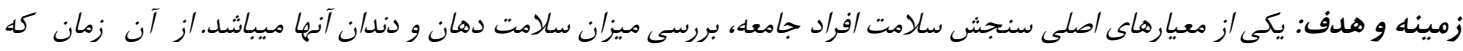

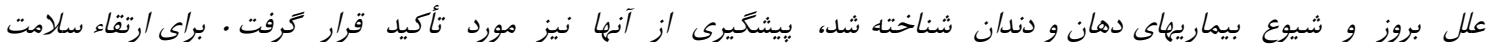

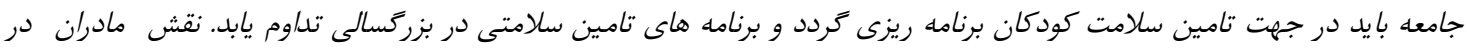

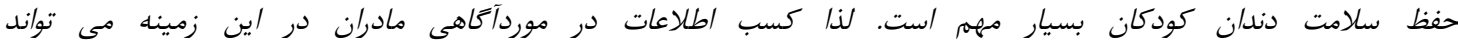

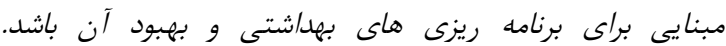

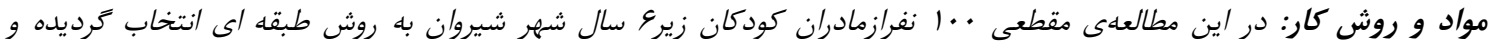

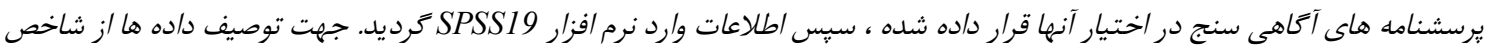

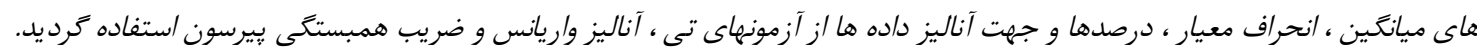

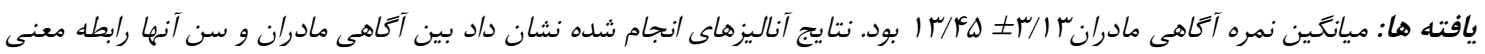

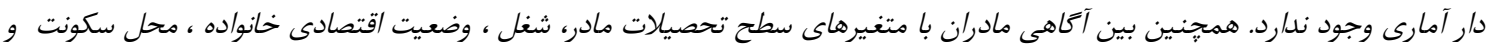

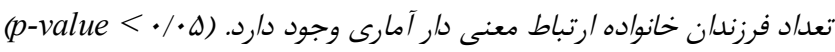

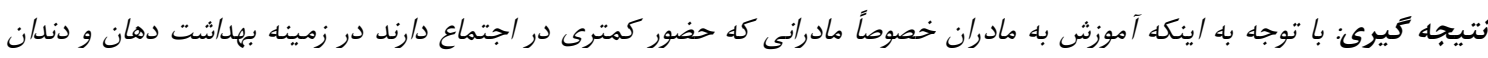

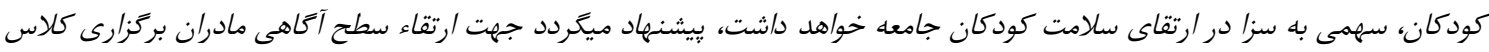

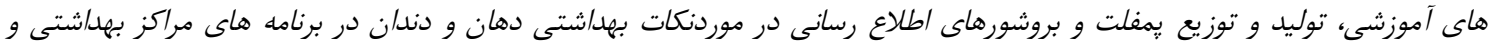 درمانى قرار كيرد. وازه هاى كليدى: آكاهى ، بهد/شت دهان و دندان

اصل فرهنگى اجتماعى است بلكه از ضروريات اعتقادى و

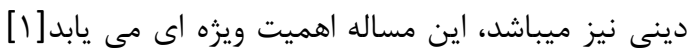
يوسيدگى دندان هاو بيمارى هاى ير يودنتال از جمله شايع

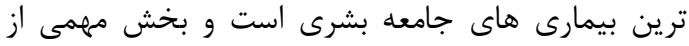

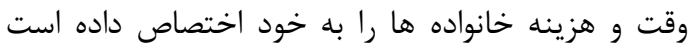

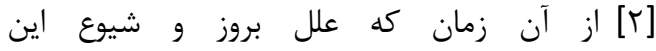
بيماريها شناخته شد، پِيشَيرى از آنها نيز مورد
مقدمه

يكى از معيارهاى اصلى سنجش سلامت افراد جامعه،

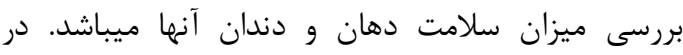
جوامع امروزى با توجه به افزايش ارتباطات وحضور افراد

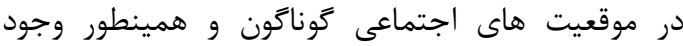
اعتقادات مذهبى در مورد بهداشت دهان و د دندان كه تاكيد بر اين دارد كه رعايت بهداشت دهان و دندان نه تنها يك دهر 
ى اصلى بهداشت دهان و و دندان كودكان هستند[9].متاسفانه اغلب والدين به دندان هاى شيرى

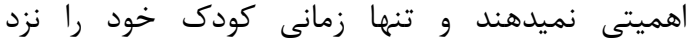
دندانيزشك ميبرند كه درد شديد، امان اورا بريده باشد ويا

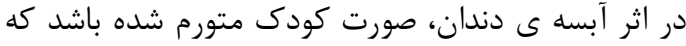
در اينكونه موارد جز كشيدن دندان هاى شيرى خارئ داره اي

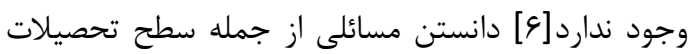

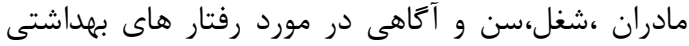

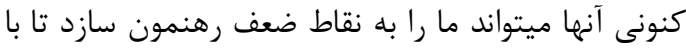

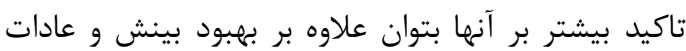

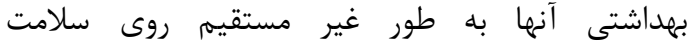

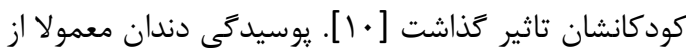

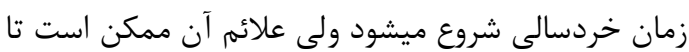
جند سال، هم از نظركودى و هم از ديد والدين و ماند دندانيزشك ،مخفى بماند [11].در كودكان إتآساله والدين به عنوان مراقبت كنندكان اصلى جهت اقدامات بهداشت دهان و دندان محسوب ميشوند.آموزش به كودك إنى در موردمسواك زدن ،مقدار خمير دندان (به اندازه يك دنى نخود)و استفاده از نخ دندان توسط والدين انجام ميشود.در

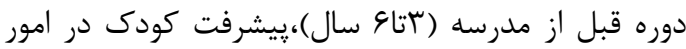
بهداشتى دهان و دندان آغاز ميشود،اما هنوز والدين تامين دئن

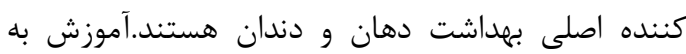
والدين بايد در راستاى نياز هاى فردى كودى و والدين و

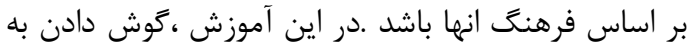

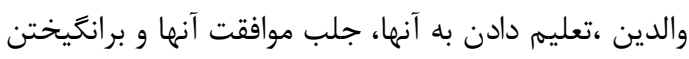

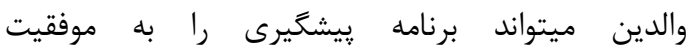
برساند.[9]|نصارى مقدم در مطالعه اى كه در مورد بررسى دئي

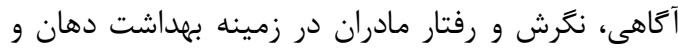
دندان كودكان شيرخوار انجام داد، نشان داد داد كه بين بهان آكاهى و رفتار مادران با بهداشت دهان و و داندان اندان

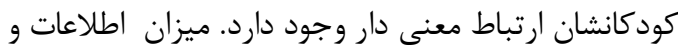

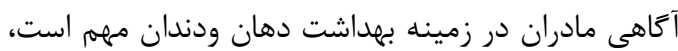

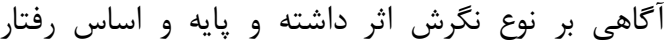
بهداشتى مناسب است[ [I [I] با عنايت به شعار سازمان

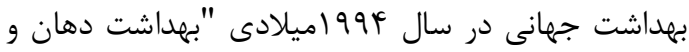

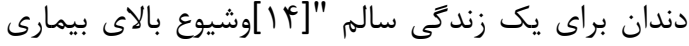
هاى دهان و دندان در ايران[10]
تأكيد قرار كرفت. كاهش بيماريهاى دهان و دندان

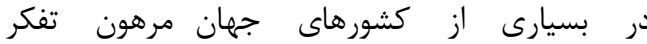

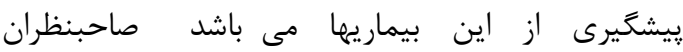

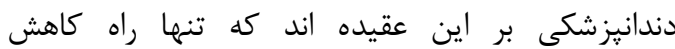

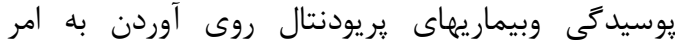
بيشخيرى است ونخستين كام در يِيشَيرى نيز

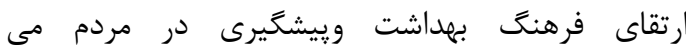
باشد[ץ] آكاهى ؛ ميزان معلومات فرد است كه ازئ

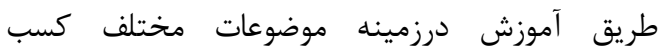

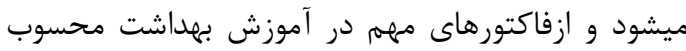

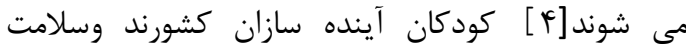
جسمى ،روانى و اجتماعى آنها آينده ايى بهتر ران نويد

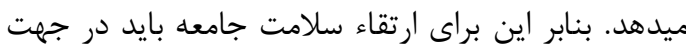

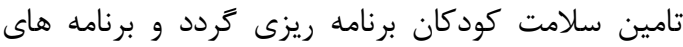

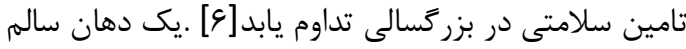

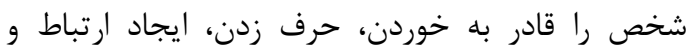

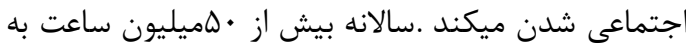

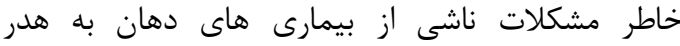

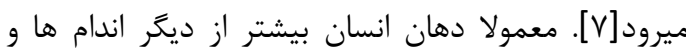

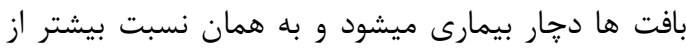
ساير قسمت هاى بدن نياز به مراقبت دارد.يوسيدگى بـى

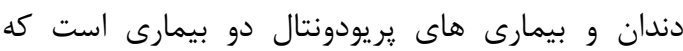

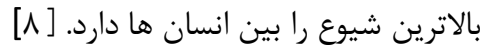

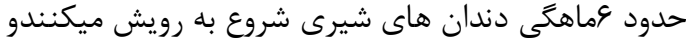

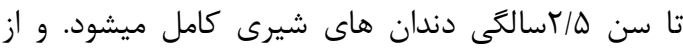
سن وسالكى دندان هاى دائمى شروع به رويش ميكنيندئ دانديه تدريج جايكزين دندان هاى شيرى ميشوند. رويش دندان

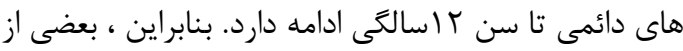

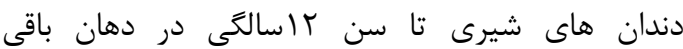
ميمانند.دندان هاى شيرى علاوه بر كاركردهايى نظير نائ

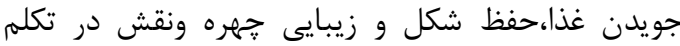
كودى وظيفه ى مهم ديخرى نيز دارند كه عبارت از حفظ فضاى لازم براى رويش دندان هاى دائمى است. مراقبت از دهان و دندان بايد از كودكى شروع شود، زيرا تنها با انجام مراقيت هاى ويزه از دندان هاى شيرى كودكان است كه دئ دان

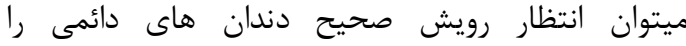

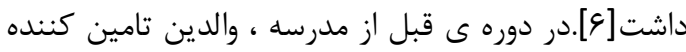


هاى بهداشتى درمانى شهرستان شيروان تعداد نمونه را

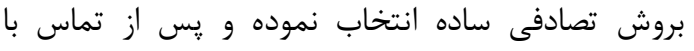

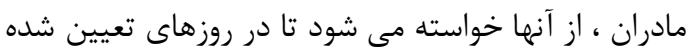

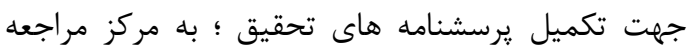
نمايند. ابزار كرد آورى اطلاعات در اين يزوهش، يرسشنامه اى

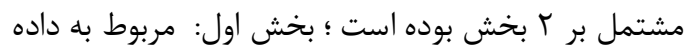
هاى دموكرافيكى از قبيل سن ، تحصيلات مادر ، تعداد

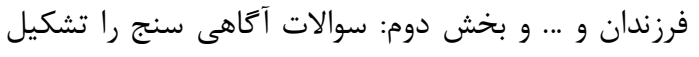

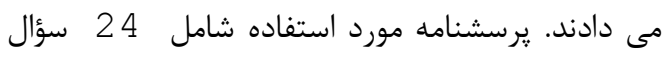

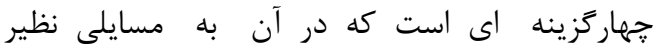

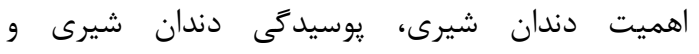

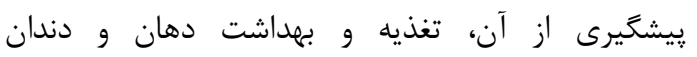
كودكان 1 تا 6 سل سال مورد سوال قرار كرفته است.

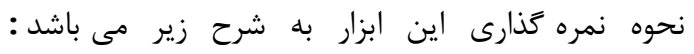

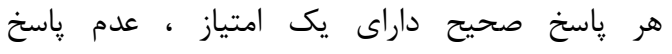

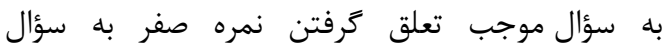

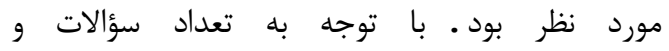

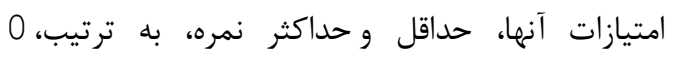

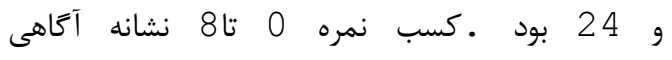
ضعيف، 9 تا 16 نشانه آكاهى متوسط، وكسب نمره 17 تا 24 نشانه آكاهى خوب

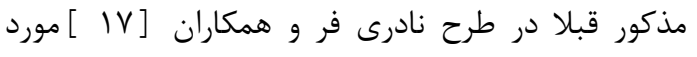

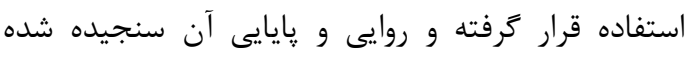

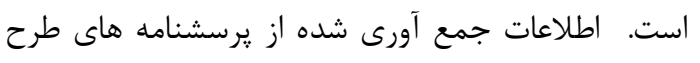

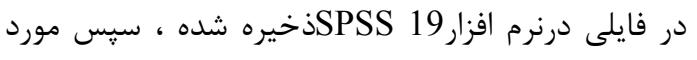

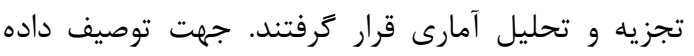
هاى طرح از شاخص هاى آمار توصيفى ميانكين ،انحراف تراف

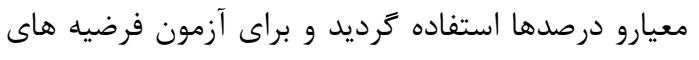

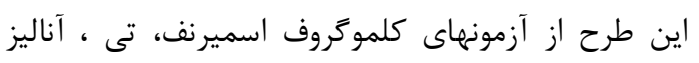

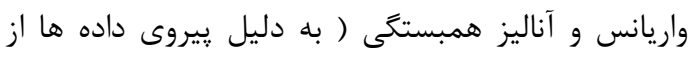
توزيع نرمال ) استفاده كرديد.

يافتهها

نتايج نشان داد ميانكين سن مادران مطالعه

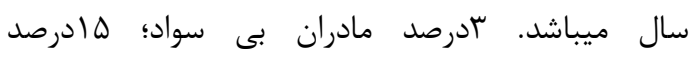

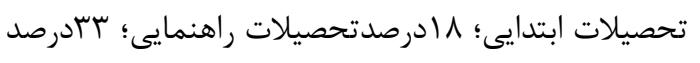

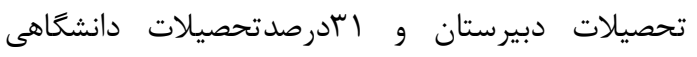

/ DDMF احساس مى شد.Decay:دندانى كه ضايعه در سطوح إنى

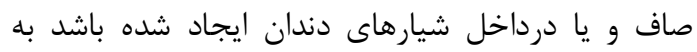

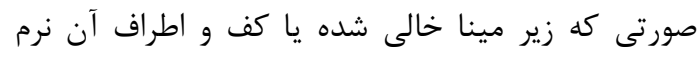

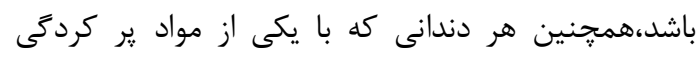

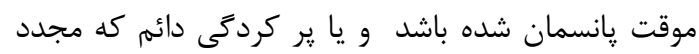

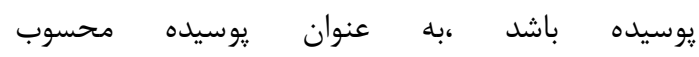

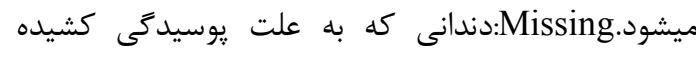

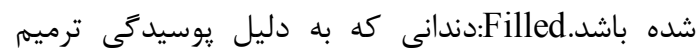
شده باشد) [19 از آنجايى كه بر اساس مطالعات الناء انجام شده بيمارى هاى

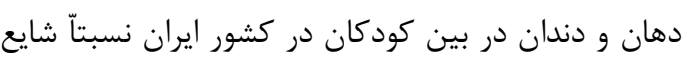
است واز طرفى ،امكانات و خدمات دندان يزشكى دئ به ويز دئه

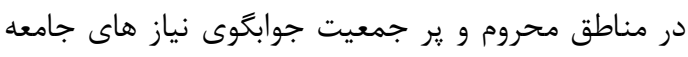

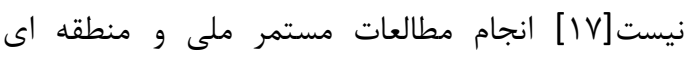

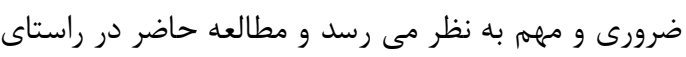

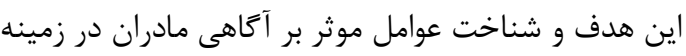

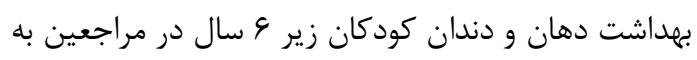

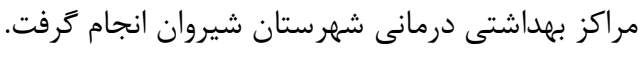
روش كار

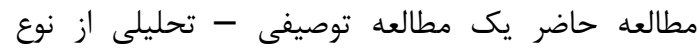
مقطعى است كه در سال |

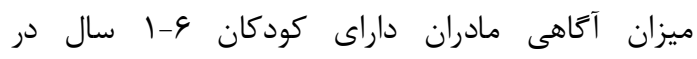

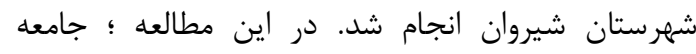

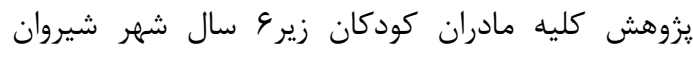

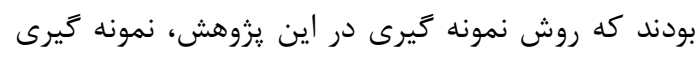

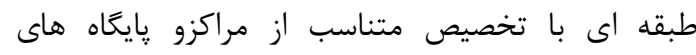

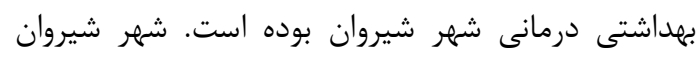

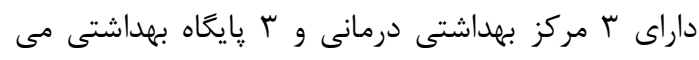

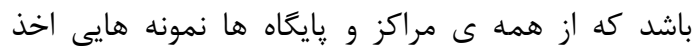
كرديد. جهت رسيدن به اهداف اصلى اين مطالعه بيشترين

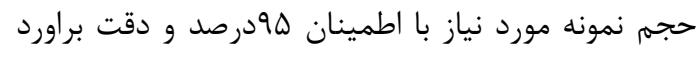

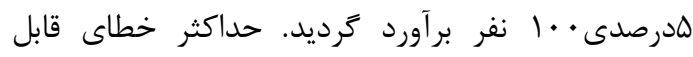

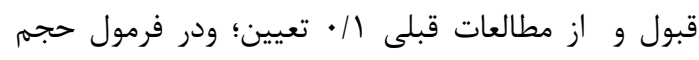
نمونه جايكذارى شده است.

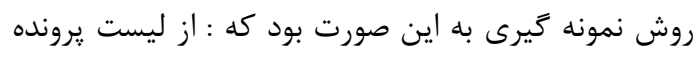
هاى كودكان ا تاع سال مراجعه كننده به مراكز و وِايعاه 
ابتدايى و مادران داراى تحصيلات دبيرستان و دانشگاهى

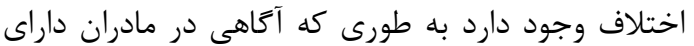

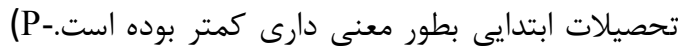
Vlue<0/05)

بين آكاهى مادران داراى تحصيلات راهنمايى و مادران

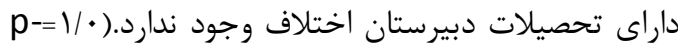

(value

بين آكاهى مادران داراى تحصيلات راهنمايى و مادران

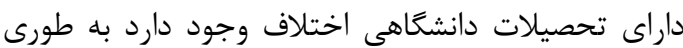

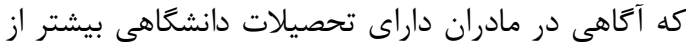
مادران داراى تحصيلات راهنمايى بود. (P-Vlue>0/05) بين آكاهى مادران داراى تحصيلات دبيرستانى و مادران داراى تحصيلات دانشكاهى اختلاف وجود دارد به طورى

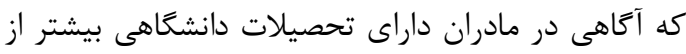
مادران داراى تحصيلات دبيرستان بود.(P-Vlue>0/05)

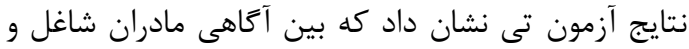
غير شاغل تفاوت معنى دار آمارى وجود دارد بطان بطوريكه

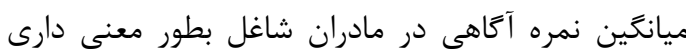

بيشتر بوده است.(P-Vlue>0/05)

همجنين نتايج آناليز واريانس بين متغيرهاى وضعيت

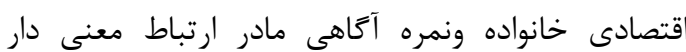

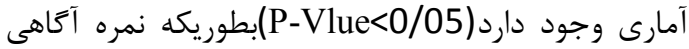
درمادران داراى وضعيت اقتصادى ضعيف بطور معنى دارى

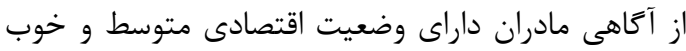

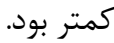

داشتند. از نظر شغل مادر : 9 ولدرصد مادران خانه دار؛ • ادرصد شاغل كاردولتى و الدرصد داراى كار آزاد بودند. در نمونه مورد بررسى لهادرصد داراى وضعيت اقتصادى

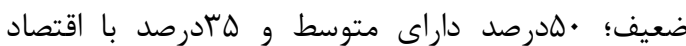

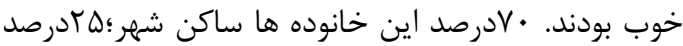
ساكن روستا و لدرصد ساكن حومه شهر بودند.

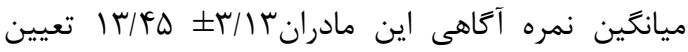
شده است. همجنين عدرصد مادران آكاهى إين مايين(نمره

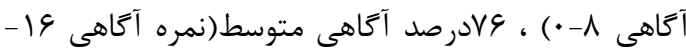

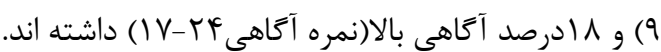

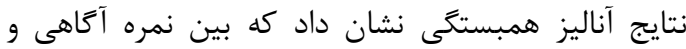
سن مادران ؛ارتباط معنى دار آمارى وجود نداشت. (مقدار

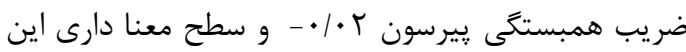
ازمون/1/ تعيين شده است) همجنين نتايج آزمون آناليز

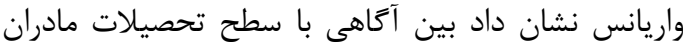

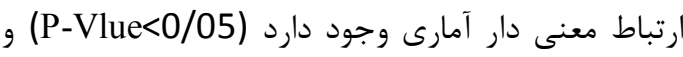

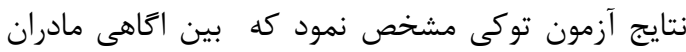
بيسواد و مادران داراى تحصيلات ابتدايى اختلاف معنا دار

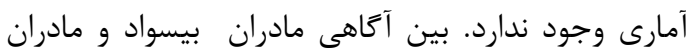
داراى تحصيلات راهنمايى، دبيرستان ، دانشكاهى اختلاف

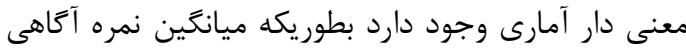

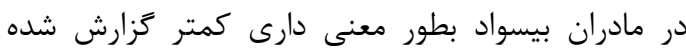

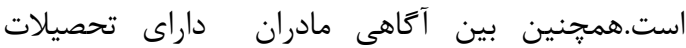
ابتدايى و مادران داراى تحصيلات راهنمايى اختلاف وجود

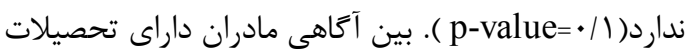

جدول ا: سطح آكاهى مادران به تفكيك سطح تحصيلات

\begin{tabular}{|c|c|c|c|c|c|}
\hline \multicolumn{6}{|c|}{ سطح تحصيلات مادر } \\
\hline دانشخاهى & دبيرستان & راهنمايى & ابتدايى & بيسواد & سطح آكاهى \\
\hline$\%$ & $\%$. & $\% / \Delta / 9$ & \% & $\% .99 / \mathrm{V}$ & يايين \\
\hline$\% \Delta \wedge / 1$ & $\% . \wedge V / 9$ & 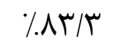 & $\% . \Lambda \& / V$ & 每 & متوسط \\
\hline$\% 19 / 9$ & $\% 9 / 1$ & $\% 11 / 1$ & $\% \cdot$ & $\% \cdot$ & بالا \\
\hline$\% 1$. & $\% 1$. & $\% 1$. & $\% 1 \cdots$ & $\% 1$ & جمع \\
\hline
\end{tabular}


جدول r: درصد ياسخ هاى داده شده صحيح و غلط به هر يك از سوالات يرسشنامه

\begin{tabular}{|c|c|c|c|}
\hline درصد پِاسخ غلط & درصد ياسخ صحيح & 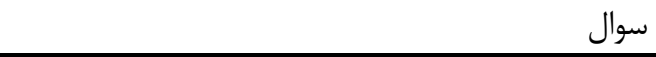 & شماره سوال \\
\hline 1 & 99 & نقش دندان در سلامت و تغذيه كودى & 1 \\
\hline$\wedge$. & $r \cdot$ & تعداد دندان شيرى & t \\
\hline$\wedge 1$ & 19 & اقدامات لازم در زمان يوسيدگى دندان كودى & r \\
\hline it & $\wedge \Lambda$ & سن رويش دندان دايمى & r \\
\hline 9 & 91 & مواد بى تاثير بر يوسيدگى دندان & $\Delta$ \\
\hline 1 & 99 & موادى كه بيشترين تاثير را بر يوسيدگى دندان دارد & द \\
\hline is & $\Delta F$ & اقدامات لازم جهت كاهش يوسيدگى دندان شيرخوار & $\checkmark$ \\
\hline r) & Vq & مواردى كه يوسيدگى دندان شيرى را كاهش ميدهد & $\wedge$ \\
\hline $1 \cdot$ & 9. & ميان وعده خوب جهت كاهش يوسيدكى دندان كودى & 9 \\
\hline$\vee \Delta$ & ra & زمان شروع مسواك زدن & $1 \cdot$ \\
\hline er & $\Delta \wedge$ & زمان مناسب مسواك زدن در شبانه روز & 11 \\
\hline$\Delta r$ & iv & زمان استفاده از نخ دندان & ir \\
\hline v9 & YI & فاصله زمانى تعويض مسواى كودى & Ir \\
\hline ir & $\wedge \vee$ & لزوم مسواك زدن دندان كودى & 14 \\
\hline$\wedge \Delta$ & 10 & وسيله تميز كردن بين دندان & 10 \\
\hline ir & $\wedge \Lambda$ & مهمترين معيار انتخاب خمير دندان & 19 \\
\hline Ve & TF & زمان شروع استفاده از خميردندان براى كودى & IV \\
\hline $1 \cdot$ & $9 \cdot$ & نقش خمير دندان & 11 \\
\hline If & $\wedge \varepsilon$ & تاثير فلورايد بر دندان ها & 19 \\
\hline 94 & 4 & طول نخ دندان & $r \cdot$ \\
\hline$\wedge \cdot$ & $r \cdot$ & حالت نخ دندان كشيدن & rI \\
\hline$\wedge$ & 94 & محل هايى كه نياز به نخ دندان كشيدن دارند & rt \\
\hline$\wedge \vee$ & r & زمان اولين مراجعه به دندان يزشك جهت كودى & r \\
\hline 99 & my & فاصله زمانى مراجعه به دندان يزشك & ry \\
\hline
\end{tabular}

نتايج آناليز همبستگى نشان داد كه بين نمره آكَاهى

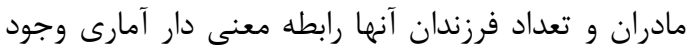

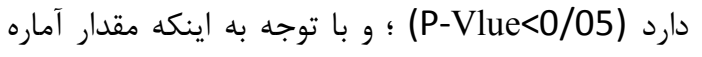

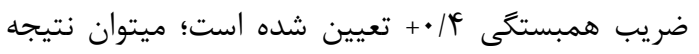

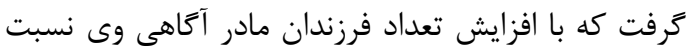
به مسائل بهداشن دهان و دنان نيز بالاتر مى رود.
نتايج آناليز واريانس نشان داد بين متغيرهاى محل سكونت

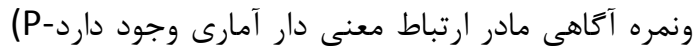
بطlue>0/05) هاى ساكن شهر بطور معنى دارى از ساكنين در روستاها و ودادئ حومه شهر بيشتر بود(P-Vlue>0/05) 


\begin{tabular}{|c|c|c|c|}
\hline \multicolumn{3}{|c|}{ وضعيت اقتصادى } & \multirow[b]{2}{*}{ سطح آكاهى } \\
\hline خوب & متوسط & ضعيف & \\
\hline$\% / \% / 9$ & $\%$ & $\%$ \% $/ \mathrm{V}$ & يايين \\
\hline$\% .9 \mathrm{D} / \mathrm{V}$ & $\% . \wedge 9$ & $\% .991 \mathrm{~V}$ & متوسط \\
\hline$\% / r / / 4$ & $\%$ & $\% .9 / \mathrm{V}$ & بالا \\
\hline$\% 1$. & $\% 1$. & $\% 1$. & جمع \\
\hline
\end{tabular}

\begin{tabular}{|c|c|c|}
\hline \multicolumn{2}{|c|}{ وضعيت اشتغال } & \multirow[b]{2}{*}{ سطح آكاهى } \\
\hline خانه دار & شاغل & \\
\hline$\%$ V/G & $\%$ & هايين \\
\hline$\% .11$ & $\% \Delta \mathrm{V} / \mathrm{I}$ & متوسط \\
\hline$\% 11 / 4$ & $\%$ FT/ & بالا \\
\hline$\% 1$. & $\% 1$. & جمع \\
\hline
\end{tabular}

برخوردار بودند [IV] ] . تحقيقى كه درسال الیr|توسط

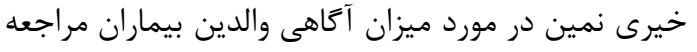
كننده به بخش كودكان دانشكده دندانيزشكى دانشخاه دآ آزاد

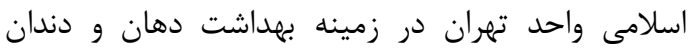

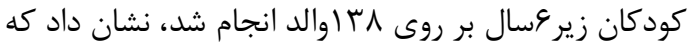

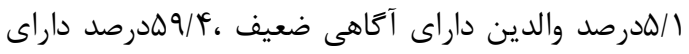

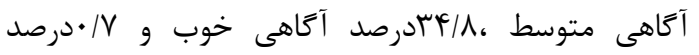

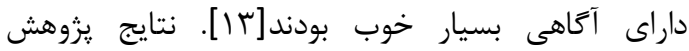

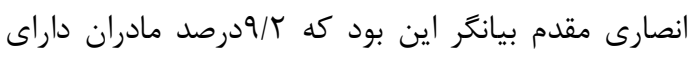

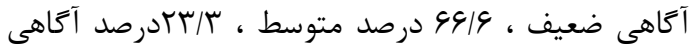

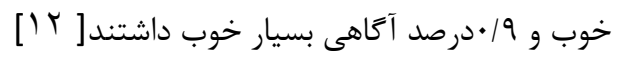

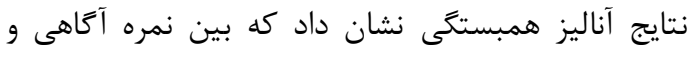

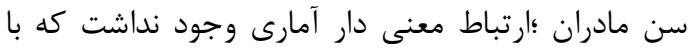
نتيجه مطالعه نادرى فر و همكاران تطابق نداشته

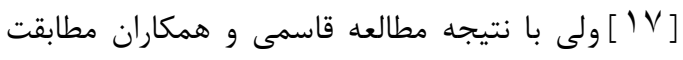

دارد. [1·
مطالعه حاضر كه بر روى . ․ نفر از مادران داراى يك يا

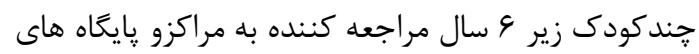

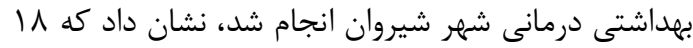

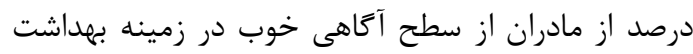

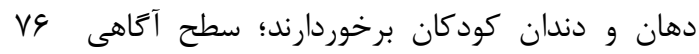
درصد متوسط و \& درصد يايين تعيين شده است و اين

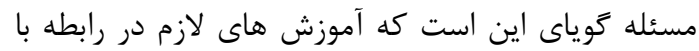

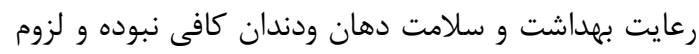

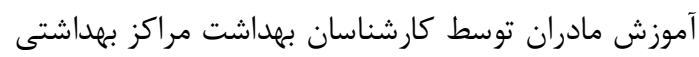

$$
\text { درمانى احساس ميكردد. }
$$

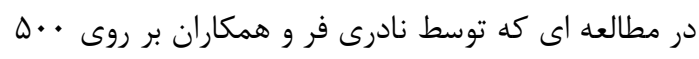

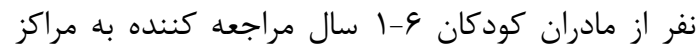

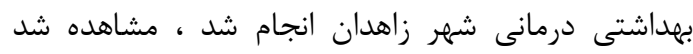
FV/F

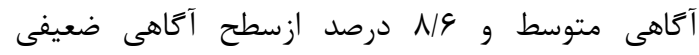


كه بر روى Bhavna ارتباط بين خصوصيات والدين با بهداشت دهان و دندان كودكانشان انجام شد ،نتايج نشان داد كه والدين نقش

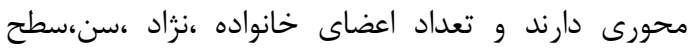
اقتصادى،قوميت،سطح تحصيلات و محل سكونت در دران بهداشت دهان تاثير دارد.زندگى شهرى باعث عملكرد بهتر و زندگى روستايى و حومه باعث عملكرد ضعيف تر

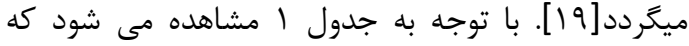

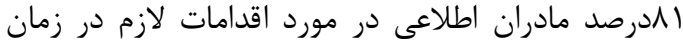

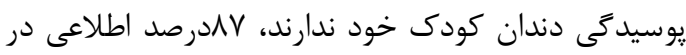

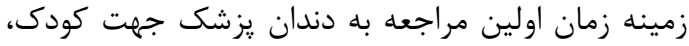
رVه

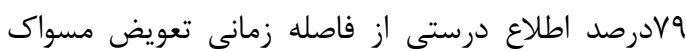

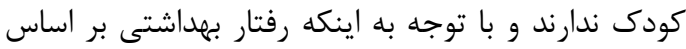

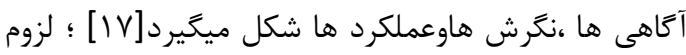

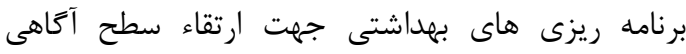
مادران مشهود مى باشد. نتيجه كَيرى از آنجا كه عموماً بين آكاهى و عملكردافراد ارتباط آمارى معنى دار موجود است مى توان نتيجه كيرى نمود كمان كه باديا

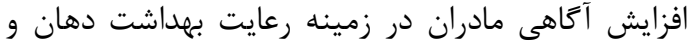
دندان كودكان 9-1 سال خود، عملكرد آنان نيز در اين اين إنان زمينه ارتقايافته و لذا آموزش به مادران خدان خصوصاً مادرانى آنى كه حضور كمترى در اجتماع دارند در اين زمينه ، سهمى إنى به سزا در ارتقاى سلامت كودكان جامعه خواهد داشت.

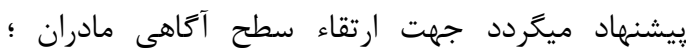
بركزارى كلاس هاى آموزشى، توليد و توزيع يمفلت و دان بروشورهاى اطلاع رسانى در موردنكات بهداشتى دهان ونان ونان

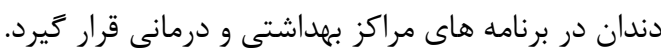

\section{تشكر و قدردانى دئ دان}

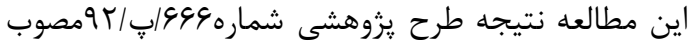

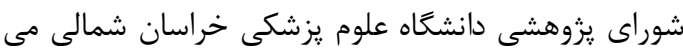

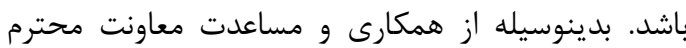
دانشخاه علوم يزشكى خراسان شمالى و همكاران محترم

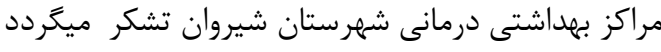

نتايج آناليز واريانس نشان داد بين آكاهى و سطح تحصيلات مادر ارتباط معنى دار آمارى وجود دارد كه اين نتيجه با نتيجه طرح نادرى فر و همكاران مطابقت دارد.در تحقيق مذكور نشان داده شد كه ميانكَين آكاهى مادران در تمام مقاطع مختلف تحصيلى با يكديكر تفاوت معنى

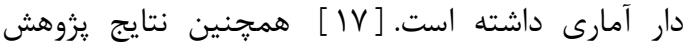
انصارى مقدم نشان داد كه بين سطح تحصيلات مادر با داريا

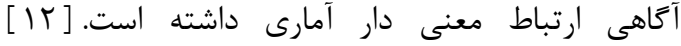
همخوانى تمام مطالعات انجام شده در اين زمينه كوياى اين است كه تحصيلات مادر بر ميزان آكاهى در زئ زمينا زمينه

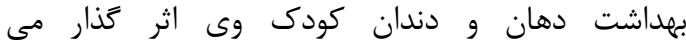

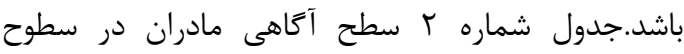

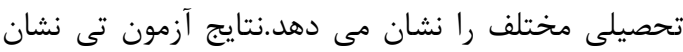

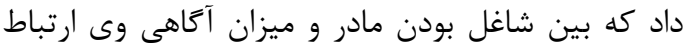

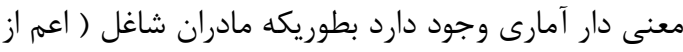

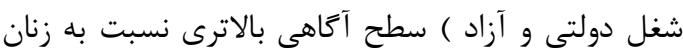

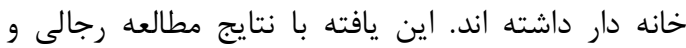
همكاران مطابقت دارد كه اين امر راميتوان به دلايلى

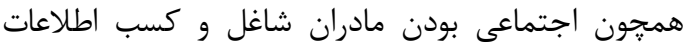

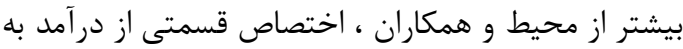
هزينه هاى درمانى توجيه نمود. در تحقيق خيرى نمين

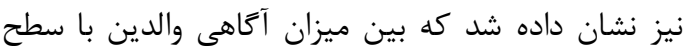
تحصيلات و شغل آنها تفاوت آمارى معنادارى وجود دارد

[IT]

نتيجه آزمون آناليز واريانس نشان داد كه بين آكاهى مادران با سطوح مختلف اقتصادى خانواده تفاوت معنى دار

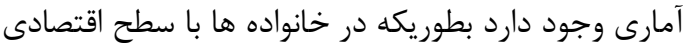

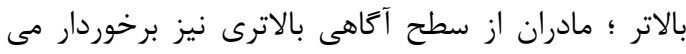

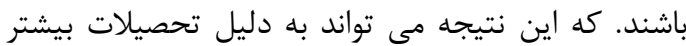
والدين ، داشتن فرزند كمتر و برخوردارى بيشتر از امكانات

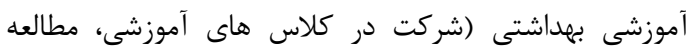
يمفلت و بروشورهاى اطلاع رسانى در موردنكات بهداشتى دهان

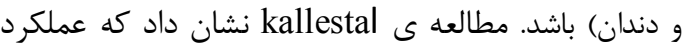
والدين بر عملكرد كودكانشان تاثير مستقيم داردو وضعيت اقتصادى،جنس،فقر،محل سكونت ،نززاد سطح اجتماعى و

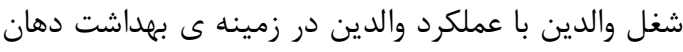
و دندان كودكانشان ارتباط مستقيم دارد[11] .مطالعه ى 


\section{References}

1. Zafarmand A.H,The study of knowledge and attitude of guidance school students in Tehran about orodental health] Persian [dissertation] Tehran: Tehran University; 2000 2. Lin HC, Wong MC, Wang ZJ, Lo EC. Oral health knowledge, attitudes, and practices of Chinese adults. J Dent Res 2001; 80 (5):146670.

3. Loupe MJ, Frazier PJ. Knowledge and attitudes of school teachers toward oral health programs and preventive dentistry. J Am Dent Assoc 1983; 107(2): 229-34.

4. Keogh T, Linden GJ. Knowledge, attitudes and behaviour in relation to dental health of adults in Belfast, Northern Ireland. Community Dent Oral Epidemiol 1991; 19 (5): 246-48

5. Poorhashemi S.J, A survey on the knowledge of health system personel in Ghom province toward oral and dental health, Journal of Dentistry. Tehran University of Medical Sciences : 2004:17(3);77-82

6. Khedmat S, Orodantal diseases Tehran: Saman Publications; 2001: 12-32

7. Kwan SY, Petersen PE, Pine CM and Borutta A. Health promoting schools: An opportunity for oral health promotion. Bull World Health Organ 2005;83(9):677-684.

8. Russell WB. Oral Hygiene Lea and Febiger. Philadelphia: Mosby; 1999. P. 539.

9. Whaley L, Wong D. Nursing care of infant andchildren.Washington Mosby; 2006: 727728

10.Ghasemi B. [The knowledge of the importance oforodental health among mothers referred toZahedan health care centers] Persian[dissertation]. Zahedan: Zahedan University ofMedical Sciences and Health Services; 2004
11. McDonald RE, Avery DR. Dentistry for the childand adolescent. St Louis: Mosby; 2000. P.3-11-12.

12. Ansari-Moghaddam S. [Mothers' knowledge and attitude towards factors affecting orodental health infants and children] Persian [dissertation]. Zahedan: Zahedan University of Medical Sciences and Health Services; 2003.

13. Khayrinamin A, [Parents'knowledge about orodental health referred to unit peadiatric of dentistry] Persian [dissertation]. Tehran: Tehran University; 2002.

14. Wong MC, Lo EC, Schwarz E and Zhang HG Oral health status and oral health behaviors in chinese children. J Dent Res 2001; 80(5): 1459- 1465.

15. Najafi A,[ Parents's knowledge about orodental health referred to Shahid Beheshti dentistry] Persian [dissertation]. Tehran: Tehran University; 2000.

16. Naderifar M, Ghaljaei F, Akbarizadeh M. $\mathrm{R}$, Determination of the mothers' practice about orodental health of their children up to six years old, ZJRMS , 2010;12(4) :43-48

17. Naderifar M, Akbarsharifi T,Pairovi $H$, Haghani H, Mothers' Awareness, regarding Orodental Health of their Children at age of 1-6 Years old ,2006; 19(46): 15-27

18. Kallestal C, Dahlgren L, Stenlund H. Oral health behavior and selfesteem in Swedish adolescents over four years. J Adol Health 2006; 38(5): 583- 90.

19. Talekar BS, Rozier RG, Slade GD and Ennett ST. Parental perceptions of their preschool-aged children's oral health. J Am Dent Assoc 2005; 136(3): 364-372. 
Original Article

\title{
Mothers' Awareness, regarding Orodental Health of their Children at age of 1-6 Years old in Shirvan
}

\author{
Nazari $Z^{1}$, Taherpour $M^{2} *$ \\ ${ }^{1}$ Public Health student at North Khorasan University of Medical Sciences, Bojnurd, Iran \\ ${ }^{2}$ M.Sc of Biostatistics, North Khorasan University of Medical Sciences, Bojnurd, Iran
}

\author{
*Corresponding Auther: \\ North Khorasan University of \\ Medical Sciences, Bojnurd, \\ Iran, \\ E-mail: \\ mtp_may1980@yahoo.com
}

\begin{abstract}
Background \& Objectives: Evaluation of oral health is one of the main criteria in public health assessment. Since the time of Prevalence and incidence of oral diseases were known, their prevention has been emphasized. Planning for children health is necessary to improve the society health. Programs of providing health condition in adulthood must be continued. Mother's role is very important in the children's dental health. So, data gathering about mothers' awareness in this area can be useful for planning health promotion.
\end{abstract}

Material \& Methods: In this cross-sectional descriptive analytical study, 100 Mothers having children less than 6 years old were selected in Shirvan by stratified random sampling method. Their Demographic and Knowledge data were collected using a valid and reliable questionnaire. Data were analyzed by SPSS-19 software and presented with descriptive (Mean and Standard deviation) and analytic statistic (t-test, Correlation analysis and Analysis of Variance)

Results: The average of Mothers' Awareness was 13/45 $\pm 3 / 13$. The results of analyzes showed no Significant relationship between the mothers' awareness and age. There was a Significant relationship between the mothers' awareness and level of education, employment, economic situation of the family, habitat and number of children. (P-Value $<0 / 05)$

Conclusion: With respect to the oral health education of mothers, especially mothers who are less socially could have an important impress on the health of children. It is recommended to raise awareness of mothers by holding educational classes, Producing and distribution of information pamphlets and brochures on oral health in health centers.

Key words: Awareness, Oral Health 